\title{
Informatics Approach to Innovative Site Management Practices for Improving Construction Works
}

\author{
Lekan Amusan $^{1,2}$, Clinton Aigbavboa ${ }^{2}$, Tolulope Olubiyi ${ }^{1}$, Ogunbayo Babatunde ${ }^{1,2}$
}

\begin{abstract}
Worldwide, the construction industry is currently experiencing dynamics in innovations, particularly in managing construction sites. The dynamic nature of operations and procedure has necessitated a change in traditional practices' paradigm to conventional techniques. To this end, this study aims to introduce new strategies that could improve management practices on projects in order to enhance project productivity and performance. A literature review has been conducted in order to establish the gaps in research already carried out, while the emerging gaps have formed the core of the research questions used for the study. A survey design has been used while the population frame of 150 construction firms has been adopted. In addition, 80 respondents that constitute professionals that work in the firms have been picked randomly for the study. Some tests like Chi-square test, Student-T test, Man-Whitney U test, simple percentage, and agreement index have been used to process the data. The following variables have been censored, analyzed, and discussed: the prevailing construction practice, the management practices of construction firms, success factors that influence efficient adoption of site management practices, problem or hindrance associated with some selected site management practices, merit in engaging management tools in construction operation management, construction professional's perspective on strategies to improve construction management practices for effective deployment, new innovations that could enhance and complement existing management practice, the barriers to effective deployment of the innovative methods. In conclusion, this study has developed new innovative strategies that could be used on-site and framework of application in the form of a site logic regression model. Most of the parameters of the model are client-project-stakeholders oriented, for instance. Some of them include resources synergy oriented procurement route, adopting a user performance expectation oriented procurement system at all the phases of the project, consultative decision approach by management, collaborative decision process, and adopting key performance indicator based procurement system. The consultative decision-taking approach entails the consultative decision taking on consulting with relevant stakeholders before taking a position on an issue. It allows the management to have workers' welfare and interest at heart while taking the decision. This is pointing to the fact that an inclusive system would be an ideal system when output is the design and model based on users' requirements. This would enable the user of a system to model a product based on their performance expectation. This study recommends the application of the new ideas suggested as a panacea to enhanced site productivity. Copyright $@ 2021$ Praise Worthy Prize S.r.l. - All rights reserved.
\end{abstract}

Keywords: Informatics, Innovation, Performance, Collaboration, Synergy, Strategy, Operation

\section{Nomenclature}

RAI

SD

Arch

Bldr

$\mathrm{N}$

$\mathrm{F}$

W

DF

Q.S

H.N.D

MBA
Relative Agreement Index

Standard Deviation

Architecture

Builder

Number

Factor

Kendal coefficient

Degree of freedom

Quantity Surveyor

Higher National Diploma

Master of Business Administration
Ho

Hi

p.cal

P.value

P. Statistics

CAD

3-D

SA

A

D

$\mathrm{N}$

$\mathrm{N}$

$\mathrm{U}$
Null hypothesis

Test hypothesis

Calculated probability value

Probability value

Statistical probability value

Computer Aided Design

3-dimension design

Strongly Agree

Agree

Disagree

Neutral

Number

Kendal Unit 


$\begin{array}{ll}\mathrm{R} & \text { Regression value } \\ \mathrm{I} & \text { Intge } \\ \mathrm{W} & \text { Wilcoxon value } \\ \mathrm{X} & \text { chi-value }\end{array}$

\section{Introduction}

Construction industry is one of the vital industries that usually boost the nation's economy after the production sector. The building is responsible for regulating a nation's economic process. It is accounted to be responsible for providing a means of livelihood for the working class of a nation. It also boosts the work force and the capital base of nations. In the construction industry, building units and facilities are some of the desirable products from the sector. The products range from residential accommodation office, office accommodation, religious and commercial accommodation, among others. The construction industry is multidisciplinary in nature. It involves carefully knit together the construction portfolio. The portfolio can also be described as cost centers, which could be configured on project documents in elemental or trade format. In the first one, activities are arranged in order of preference, while trade format presents work items in the form of the interdependence of a trade to the next. Considering the content of the cost centers, they tend to be multidisciplinary in nature. For instance, one cost center could be broken down into components such as materials needed for execution, workmanship, monetary resources, cost, and time. In the construction industry, there have been menace of project abandonment, scarcity of labor, and cost overrun among others plaguing the construction industry, and interestingly most of the vices listed are offset of inadequate management of project technique and an improper decision taken that has occurred over time. For instance, project abandonment usually starts at the decision-taking stage, sometimes due to wrong interpretation of clients' brief, wrong project composition, inadequate capturing of project details, all the mentioned parameters tend to induce project abandonment. There are targeted management techniques that could be adopted in order to forestall project vices on sites. Therefore, to this end, this study has set off to achieve profiling and documenting some innovative techniques for managing works on construction sites.

Construction site management, according to [9], [12] mainly involves the management of the construction process, resource management (which includes; management of capital, labor-management), both skilled and unskilled, dynamic management of plants and equipment, material management, the method used in procuring site resources and in-situ production process management among others. It directly influences construction quality, cost, and time of delivery.

Therefore, there is the need for the choice of an effective and efficient method that would lead to the effective management of site resources in a way that client could have value for money invested in the project.
Therefore, this study has attempted to develop an innovative approach that could possibly be used in a way that would serve as an innovation that would bring productivity enhancement. Since ancient times, this is regarded as a crux of any business. Management practice is an act of engaging different management tools. There are different approaches to management. According to [1], there are two approaches to management practice since ancient times in the Roman Empire; they include the classical approach and the modern approach. The first one was developed in the eighteenth century; the second one was invented in 1880 and perfected in 1920. In the classical approach, effective deployment and application of management techniques and tools is the priority in any production process. The classical approach involves the application of some of the following focal points: scientific management, bureaucratic management, and administrative management, among others. Friedrich Winslow, in 1856, developed approaches in a scientific application in management. The approach was developed using time, and motion study, job piece-rate allocation, project supervision, human resources recruitment and training, and cooperation among workers and managers.

Motion study involves the real-time observation of workers in order to ascertain the actual operation time for a task. It helps in evaluating and measuring of the performance of a worker as relates to an activity. In addition, jobs are allocated on a ration basis in scientific management, and this often helps in leveraging labor charge and compensation. Similarly, from 1841 to 1925 , a French researcher, Henri Fayol, developed administrative principles that were orientated towards developing ideals that could help managers at managerial levels. To this end, Henri Fayol developed 14 management ideals, which include discipline, remuneration, and agreement in direction, centralization of operations, and a sense of spirit-de-corps, among others. Furthermore, in scientific management, bureaucratic management has been also invented. The conceptualization and the configuration of the bureaucratic movement have been consummated by Max weber. Therefore, the aim of this study is to study and present an innovative approach that could be adopted in managing construction works with a view to enhance site productivity. In addition, in the context of this study, the study tries to provide a solution to the following research questions as touching the subject matter in consideration.

Some studies have been reviewed in order to bring out some gaps. Some of the areas covered in previous studies include but are not limited to, the following: Towards Improving Site Management [2], In search of project classification [3], "Key Performance Indicators and Assessment Methods for Infrastructure Sustainability [4] "Causes of delay and cost overruns in construction [5], "A Competency Framework for Construction Supervisors in Developing Countries [14], Innovation in the Construction Industry [7], Critical success factors in R\&D projects, innovation and project management [8], among others. The research questions arouse on account 
of gaps identified in some selected literature. Some of the gaps include, among others, prevailing construction management practice, the importance of management tools, the barrier against the effective adoption of management tools, new innovative management practice, and new innovation that could compliment a new one.

The questions include:

i. What are the prevailing construction site management practices of construction firms?

ii. What are the success factors that influence the efficient adoption of site management practices?

iii. Is there any problem or hindrance associated with some selected site management practices?

iv. Is there any merit in engaging management tools in construction operation management?

v. What is the construction professional's perspective on strategies to improve construction management practices for effective deployment?

vi. Are there innovations that could enhance and complement existing management practice?

vii. What are the barriers to the effective deployment of innovative methods?

Therefore, to this end, the authors have engaged the survey approach in carrying out the research, while a random sampling technique has been used in picking the samples. The study is structured in the following order: literature overview, materials, and method result from presentation and discussion, recommendation, acknowledgment, and references.

The following parameters have been profiled and censored in the study: the existing management practices, the factors influencing site management practices, the challenges of site management practices, the application of management tools in practice, the comparative analysis of construction professionals perspective on innovative strategies to the best site management practice, the critical success factors that influence innovation approach on sites and the framework that can guide the adoption of innovative management practice on site.

This study is structured into sections and subsections in the following order. Section I contains the Introduction, Section II contains the research materials and the method. Data presentation and processing have been presented in Section III. Section III has been divided into the following subsections: the prevailing construction practice, the management practices of construction firms, success factors that influence efficient adoption of site management practices, problem or hindrance associated with some selected site management practices, merit in engaging management tools in construction operation management, construction professional's perspective on strategies to improve construction management practices for effective deployment, new innovations that could enhance and complement existing management practice, the barriers to effective deployment of the innovative methods.

Conclusion and recommendations are illustrated in Section IV.

\section{Review of Selected Literature}

Recent advances in the application of informatics to solve problems in the construction field cover site inspection, inventory management, automation of prefabricated houses, and application of robots in the construction and communication system. In [10], the ways in which automation has greatly influenced construction works have been presented. The study has stated, among other things, an innovative system that could be adapted in order to create improvement in tool and equipment applications. Some of them include digital leveling, automated leveling instruments, digital benchmarks. In site inspection and monitoring, drones are often deployed in site monitoring and control of activities on sites. In the construction of high-rise buildings and skyscrapers, drones are usually used in site monitoring, security monitoring for reporting, and control of construction activities on site. The site happenings are monitored in real-time, and the reports are sent electronically to a remote server for further collation retrieval and processing. Robots are also deployed in construction activities in developing countries. For instance, in Asia, robots are deployed in carrying out activities such as painting, confirmation of verticality, and horizontal nature of building structures, plastering, rendering on construction sites, among others.

In design, 3-D design protocol is gradually replacing the age-long table drafting of project drawings. For instance, with the aid of tools like Primavera, AutoCAD, 3-D dimensional design for building automation has come to reality. In addition, in the United States of America, military formations and other countries like South Korea, Singapore and Malaysia are using 3-D plotters and design tools in the construction of infrastructures such as bridges, dams, silos, bunkers, armor tank, military forts, and battlements. 3-D automation in construction is an innovation for the future, which should be keenly observed. To this end, the study has been conducted on the innovative approaches being used on construction sites for enhanced productivity with a view to eliminate them for enhanced productivity. An exploratory approach has been used to carry out a study on green construction practice by [10], and [11]. The study has used automated tools to carry out the determination of the structural integrity of building structures in Finland using a multidisciplinary approach.

The study recommends structural integrity as a priority during the construction process. [12] has conducted a study on automation in the security system of a building. The study has developed smart home security that can be used to prevent theft occurrence at homes. [13] has carried out a study on Innovations in the construction industry. The study has reviewed innovation models and has also investigated the concept of the technology adoption life cycle. The study has proposed a new model of innovation while the model has specified the following as the life cycle of innovation adoption: creation of innovation, identifying the need for the innovation, creation of the innovation hallmarks, 
diffusion of the innovation, and adoption of the innovation. [8] has addressed the similarity that exists between management practice and project management with the aid of project management indices. The study has described a workable project as a project with highperformance indices. The study has premised the trend on the performance of project variables often articulated with the aid of a project management tool. Albeit, [14] in a study entitled "a competency framework for construction supervisors in developing Countries", has described site management as planning site activities according to strategic planning, control, and coordination of project objectives, monitoring of construction process, and its portfolio. The study has advocated certain parameters for effective site management process, which include strategic project management, project coordination and control, policy formulation and implementation, among others, as a panacea to an effective project management practice. This toes the line of submission in [15] and [16]. [14] has developed a smart system for community policing and security. The study has developed a sustainable building. The smart system incorporates a mechanism to affect smoothness in building construction process and maintenance. The component of the smart system enables easy maintenance and management of building components.

\section{Research Material and Method}

A survey design has been used in this study, while the population frame of 150 construction firms has been adopted. Eighty respondents that constitute professionals that work in the firms have been picked randomly for the study. Some tests like Chi-square test, Student-T test, Man-Whitney U test, simple percentage, and agreement index have been used to process the data. The following variables have been censored, analyzed, and discussed: the prevailing construction practice, the management practices of construction firms, success factors that influence efficient adoption of site management practices, problem or hindrance associated with some selected site management practices, merit in engaging management tools in construction operation management, construction professional's perspective on strategies to improve construction management practices for effective deployment, innovations that could enhance and complement existing management practice, the barriers to effective deployment of the innovative methods.

\section{III.1. Questions Scale}

The questionnaire has been designed in Likert scale 1 to 5 as highlighted in Table I, while the data has been processed with mean item score to derive the Relative Agreement Index (RAI) of the data. RAI has been calculated using the relationship below:

$$
\frac{5 S A+4 A+3 N+4 D+5 S D}{5(S A)+4(A)+3 N+4 D+5(S D)}
$$

TABLE I

ORDINAL SCALE USED FOR CALIBRATED QUESTIONNAIRES

\begin{tabular}{cc}
\hline \hline Ordinal scale & Likert Scale \\
\hline Strongly agree & 5 \\
Agree & 4 \\
Strongly-disagree & 3 \\
Disagree & 2 \\
Neutral & 1 \\
\hline \hline
\end{tabular}

\section{Results Presentation and Discussion}

\section{IV.1. Prevailing Management Practices on Construction Sites}

Right from the ancient times, construction work has been taking place with resources like cost, time machine and tools being used, while methods to manage the resources have always been formulated. Many of the methods often used are as old as the world system. For instance, clients have been known to allocate always resources while forming the design brief, the process thus continues until client takes the ownership of the project.

In project design and configuration as a variable under types of management practices in use, respondents view about the management practice has been profiled and presented in Table II.

From the analysis, Client request forming basis of design brief and configuration (RAI 0.78) has 1 st. Selection of design team based on profiled past project performances (RAI 0.76) has been ranked 2nd.

Profiling designs based on the project scope (RAI 0.76) have ranked 2nd, while Engaging professional that has been supposed to be on project based on competence (RAI 0.75) has ranked 3rd. In project design and configuration, conforming to clients brief is of utmost importance. The basis of every design has always clients input as an essential part of any workable construction plan.

Therefore, client requests should always form the basis of design brief and configuration. Similarly, the design team should be selected on account of project consultants' advise to the client, and the professionals should be selected strictly on performance results of their previous projects and competence. This fact toes the line of a submission in [15] and [16] respectively.

In addition, construction project procurement route is another site management practice encountered. Some parameters have been documented under this variable they include, Profiling the available procurement system based on project scope and limitation (RAI0.87) has ranked 1st. Procurement system selection dependent on the type of project in consideration (RAI 0,86) has ranked 2nd. Selection of project procurement system according to the available project characteristics and type (RAI 0.86) has ranked 2nd, while calibrating requirements for selection of project team (RAI 0.78) has ranked 3rd. Construction procurement route adopted for a study is another important factor in project success. Once the aspect of choice of procurement system for a project is adequately planned, the project would move on smoothly. 
TABLE II

Profile Of Existing MANAGEMENT Practice

\begin{tabular}{|c|c|c|}
\hline Management Practices & R.A.I & Rank \\
\hline \multicolumn{3}{|l|}{ Project Design and Configuration } \\
\hline $\begin{array}{l}\text { Client request forming basis of design brief and } \\
\text { configuration. }\end{array}$ & 0.78 & $1^{\text {st }}$ \\
\hline $\begin{array}{l}\text { Selection of design team based on profiled past project } \\
\text { performances }\end{array}$ & 0.76 & $2^{\text {nd }}$ \\
\hline Profiling designs based on the project scope & 0.76 & $2^{\text {nd }}$ \\
\hline $\begin{array}{l}\text { Engaging professional that supposed to be on project } \\
\text { based on competence }\end{array}$ & 0.75 & $3^{\text {rd }}$ \\
\hline $\begin{array}{l}\text { Carrying out feasibility study prior to commencement } \\
\text { of construction project }\end{array}$ & 0.75 & $3^{\text {rd }}$ \\
\hline \multicolumn{3}{|l|}{ Construction Project Procurement Route } \\
\hline $\begin{array}{l}\text { Profiling the available procurement system based on } \\
\text { project scope and limitation }\end{array}$ & 0.87 & $1^{\text {st }}$ \\
\hline $\begin{array}{l}\text { Selection of project procurement system according to } \\
\text { the available project characteristics and type }\end{array}$ & 0.86 & $2^{\text {nd }}$ \\
\hline $\begin{array}{l}\text { Procurement system selection is dependent on the type } \\
\text { of project in consideration }\end{array}$ & 0.86 & $2^{\text {nd }}$ \\
\hline Calibrating requirements for selection of project team & 0.78 & $3^{\text {rd }}$ \\
\hline $\begin{array}{l}\text { Instituting condition of contract invoking appropriate } \\
\text { codes }\end{array}$ & 0.77 & $4^{\text {th }}$ \\
\hline $\begin{array}{l}\text { Documentation of relevant project document as project } \\
\text { guide }\end{array}$ & 0.76 & $5^{\text {th }}$ \\
\hline \multicolumn{3}{|l|}{ Pre Contract Planning } \\
\hline Setting up modality for contact award & 0.86 & $1^{\mathrm{st}}$ \\
\hline Setting up project preliminaries & 0.83 & $2^{\text {nd }}$ \\
\hline Mobilizing material and labor to site & 0.83 & $2^{\text {nd }}$ \\
\hline Instituting condition of contract & 0.82 & $3^{\text {rd }}$ \\
\hline Procurement of relevant permits and approval & 0.82 & $3^{\text {rd }}$ \\
\hline Setting up of project professionals & 0.82 & $3^{\text {rd }}$ \\
\hline Construction of site hoardings for site security & 0.81 & $4^{\text {th }}$ \\
\hline $\begin{array}{l}\text { Site accommodation, lighting, water services and } \\
\text { temporary facilities. }\end{array}$ & 0.79 & $5^{\text {th }}$ \\
\hline $\begin{array}{c}\text { Material and human resources profiling and } \\
\text { procurement }\end{array}$ & 0.77 & $6^{\text {th }}$ \\
\hline Setting of preliminary estimates and cost for project & 0.76 & $7^{\text {th }}$ \\
\hline Site Mobilization & 0.75 & $8^{\text {th }}$ \\
\hline \multicolumn{3}{|l|}{ Human Resources } \\
\hline Labor and human resources procurement & 0.86 & $1^{\text {st }}$ \\
\hline Site drilling on job safety and protection & 0.78 & $2^{\text {nd }}$ \\
\hline Remuneration and rewards & 0.77 & $3^{\text {rd }}$ \\
\hline Setting up effective job allocation system on site & 0.76 & $4^{\text {th }}$ \\
\hline
\end{tabular}

Author Survey (2019) RAI: Relative Agreement Index

There are different types of procurement that follow the pattern of variables presented, for instance, design, and build system, management contracting, and collaborative partnership procurement system among others.

In another clime, there is stockholder management system, which is often used in procurement of high tech and low-tech project. Procurement route is of outmost relevance when value for money is one of the project expectations.

This view has been supported in [13]. Similarly, some schools of thoughts have advocated greater caution at preplanning stage and project execution stage of projects.

This is on account of project variables that have often left the outcome of the project unpredictable. For instance, in Table II, intervening parameters that can influence project progress at project planning stage are profiled.

They include setting up modality for contact award (RAI 0.86) that has ranked 1st, setting up project preliminaries (RAI 0.83) that has ranked 2nd, Mobilizing material and labor to site (0.83) that has ranked $2 \mathrm{nd}$, instituting condition of contract (RAI 0.83) that has ranked 2 nd. In addition, procurement of relevant permits and approval (RAI 0.82) has ranked 3rd, while setting up of project professionals (RAI 0.82) has also ranked 3rd among others.

The trend presented above has been supported in a study carried out in [7] and [20].

\section{IV.2. Factors Influencing Effective Site Management Practices}

In construction field, there are many interdependent variables whose interplay results in project success. Some of them come in the form of law, ethics, paradigm, frameworks, and influencing factors. To this end, some of the factors that influence site management practices are presented in Table III. These factors include Project related factors, project team members related factors, procurement route related factors and external related factors. External related factors include provision of resources and alternative resources (RAI 0.80 ranked $1 \mathrm{st}$ ), adoption of relevant technology for construction work (RAI 0.80 1st), major force e.g. flood, weather (RAI 0.79 ranked 2nd), interplay of economic variables macro and micro factors (RAI 0.79 ranked 2nd).

Sometimes, alternative resources need to be provided in order to prevent project stagnancy, sometimes, adopting alternative materials lessens cost, and likewise adopting relevant technology for construction work the view has been supported in [15] and [13].

TABLE III

FACTORS INFLUENCING SiTE MANAGEMENT PRACTICES Factors Influencing Site Management Practices $\quad$ R.A.I Rank External Related Factors

Provision of resources and alternative resources $\quad \begin{array}{lll}0.80 & 1^{\text {st }}\end{array}$ Adoption of relevant technology for construction work $\quad \begin{array}{llll}0.80 & 1^{\text {st }}\end{array}$ Force majeure e.g. flood, weather etc. $\quad 0.79 \quad 2^{\text {nd }}$ Interplay of economic variables macro and micro factors $\quad 0.79 \quad 2^{\text {nd }}$ \begin{tabular}{ccc}
\hline Stakeholder Related Issues & & \\
\hline Fund availability & 0.87 & $1^{\text {st }}$
\end{tabular}

Excessive variation of plans and demand during construction

$0.871^{\text {st }}$

$\begin{array}{ccc}\text { Delay of the progress of consultants and contractors } & 0.86 & 2^{\text {nd }} \\ \text { Inaccurate project brief and project objectives } & 0.85 & 3^{\text {rd }}\end{array}$ Procurement Route Related Factors

Operating open and transparency in adoption of $\quad \begin{array}{lll}0.84 & 1^{\text {st }}\end{array}$ procurement system

Selection of right procurement system

$0.841^{s+}$

Adequate and valid composition of tendering and $\quad 0.83 \quad 2^{\text {nd }}$ procurement

Project Team Members Related Factors

Selection of competent project professionals for project execution

$0.791^{\text {st }}$

$0.782^{\text {nd }}$

Demonstration of Esprit-de-corps on project

Continuous improvement of operation during

$0.782^{\text {nd }}$ development of the project

$\begin{array}{ccc}\text { Strong corporate relationship among the stakeholders } & 0.76 & 3^{\text {rd }} \\ \text { Project Related Factors }\end{array}$

Effective selection and allocation of human resources on site Government policy

Nature of Turn-in-time of project

Size and cost value of the project Complex nature of project

$0.88 \quad 1^{\text {st }}$

$0.872^{\text {nd }}$

$0.872^{\text {nd }}$

$0.863^{\text {rd }}$

$0.863^{\text {rd }}$

Author Survey (2019) RAI: Relative Agreement Index 
Similarly, stakeholder related issues presented in the study include fund availability (RAI 0.87 ranked 1st), excessive variation of plans and demand during construction (RAI 0.87 ranked 1st), delay of the progress of consultants and contractors (RAI 0.86 ranked 2nd), inaccurate project brief and project objectives $(0.83$ ranked 2nd). In addition, [13] and [15] have discussed about necessity of good procurement system, procurement route refers to the system adopted in carrying out a project work. Therefore, in this study, procurement route related factors are shown in Table III.

Some of the associated factors include operating open and transparency in adoption of procurement system, selection of right procurement system, adequate and valid composition of tendering and procurement. Finally, project related factors as presented in the table include effective selection and allocation of human resources on site, government policy, nature of Turn-in-time of project, and Complex nature of project. It is one of the important factors that project related factors should be accorded full priority. This would enable managers have full control of the project. To this end, [14] and [21] have observed management and planning of project as a major factor that predict project success. Their view has supported the pattern of results presented above where effective selection and allocation of human resources on site (RAI 0.88 ranked 1st), government policy (RAI 0.87 ranked 2nd), nature of Turn-in-time of project (RAI ranked 2nd), Size and value of the project with Complex nature of project were with RAI 0.86 were ranked 3rd respectively). In the construction field, there are many interdependent variables whose interplay results in project success. Some of them come in the form of law, ethics, paradigm, frameworks, and influencing factors.

To this end, some of the factors that influence site management practices are presented in Table III. The factors include project-related factors, project team members related factors, procurement route related factors, and external related factors. External related factors include the provision of resources and alternative resources (with RAI 0.80 ranked 1st), adoption of relevant technology for construction work (with RAI 0.80 1st), major force, e.g., flood, weather (with RAI 0.79 ranked $2 \mathrm{nd}$ ), the interplay of economic variables macro and micro factors (RAI 0.79 ranked 2nd). Sometimes, alternative resources need to be provided in order to prevent project stagnancy. Sometimes, adopting alternative materials lessens cost, likewise adopting relevant technology for construction work the view has been supported in [15] and [13]. Stakeholder related issues presented in the study include fund availability (RAI 0.87 ranked 1st), an excessive variation of plans and demand during construction (RAI 0.87 ranked 1st), delay of the progress of consultants and contractors (RAI 0.86 ranked 2nd) while inaccurate project brief and project objectives (0.83 ranked 2nd). In [13] and [15] discussions have been centered on necessity of a sound procurement system. The procurement route refers to the approach adopted in carrying out project work.
Therefore, in this study, procurement route related factors are shown in Table III. Some of the associated factors include operating open and transparency in the adoption of the procurement system, selection of right procurement system, adequate and valid composition of tendering, and procurement. As presented in Table III, project-related factors include effective selection and allocation of human resources on-site, government policy, nature of the Turn-in-time of project, and the project's complex nature. It is one of the critical factors that project-related factors should be assigned the highest priority. This would enable managers to have satisfactory control. To this end, [14] and [21] have observed management and planning of the project as a major factor that predicts project success. Their view has supported the pattern of results presented above where effective selection and allocation of human resources on-site (RAI 0.88 ranked $1 \mathrm{st}$ ), government policy (RAI 0.87 ranked 2nd), nature of Turn-in-time of a project (RAI ranked 2nd), Size and value of the project with The complex nature of the project was rated with RAI 0.86 were ranked 3rd, respectively Project-related factors are very relevant and interfere frequently on construction activities. Some of the factors mentioned earlier include the effective selection and allocation of human resources on-site, government policy, nature of the Turn-in-time of project, and the project's complex nature. [13] has regarded it as one of the critical factors that influence construction projects. Project-related factors should be assigned the highest priority. This would enable managers to have satisfactory control. To this end [14], [15], [16] and [21] have observed management and planning of the project as a significant factor that predicts project success. Their view has supported the submissions presented in Table III, where effective selection and allocation of human resources on-site (RAI 0.88 ranked $1 \mathrm{st}$ ), government policy (RAI 0.87 ranked 2nd), nature of Turn-in-time of a project (RAI ranked 2nd), scope, nature and size and value of the project with

The complex nature of the project was rated with RAI 0.86 were ranked $3^{\text {rd }}$. This toes the line of submission in [11], [14] and [15].

\section{IV.3. Challenges Associated Existing Selected Site Management Practices}

Challenges of the site management system are presented in Table IV: error of judgment on resource calibration and acquisition (with RAI 0.88 ranked 1st), default inadequately enforcing the practice of building regulations (with RAI 0.88 ranked 1st), non-compliance with site instructions (with RAI 0.88 rated 1st), noncompliance with building specifications(with RAI 0.87 ranked 2nd), inadequate site supervision and inspection (with RAI 0.87 ranked 2nd).

In contrast, the insufficient facility for storing materials on-site and the insufficient supervision of personnel and site works with RAI 0.83 and 0.84 have been ranked 6th and 5 th. 
TABLE IV

Challenges Of Site Management Practices

\begin{tabular}{ccc}
\hline \hline Challenges of Site Management Practices & R.A.I & Rank \\
\hline $\begin{array}{c}\text { Error of judgement on resources calibration and } \\
\text { procurement }\end{array}$ & 0.88 & $1^{\text {st }}$ \\
$\begin{array}{c}\text { regulations } \\
\text { Default in sufficiently enforcing practice of building }\end{array}$ & 0.88 & $1^{\text {st }}$ \\
Non-compliance with site instructions & 0.88 & $1^{\text {st }}$ \\
Non-compliance with building specifications & 0.87 & $2^{\text {nd }}$ \\
Inadequate site supervision and inspection & 0.87 & $2^{\text {nd }}$ \\
Tools and equipment wastage & 0.86 & $3^{\text {rd }}$ \\
Lack of communication within the contractor's & 0.85 & $4^{\text {th }}$ \\
$\quad \begin{array}{c}\text { organization } \\
\text { Delay in material procurement }\end{array}$ & 0.85 & $4^{\text {th }}$ \\
Labor force that are undertrained & 0.84 & $5^{\text {th }}$ \\
Inadequate supervision of personnel and site works & 0.84 & $5^{\text {th }}$ \\
Insufficient ripening time for the concrete for concrete & 0.83 & $6^{\text {th }}$ \\
works & 0.83 & $6^{\text {th }}$ \\
\hline Ineffective facility for storing materials on site & &
\end{tabular}

Author Survey (2019) RAI: Relative Agreement Index

Similarly, in a study conducted by [20], factors such as management, workplace, work team, safety and material, and equipment are listed as factors that influence site management practices that corroborate this study's findings. An error of judgment in getting the right resources and difficulty in calibrating the types of resources needed has the potential to hinder the extent of success desirable on-site if not correctly addressed.

Likewise, non-compliance with site instructions as laid down in the work program alongside flaunting building regulations have been known to have a negative impact on construction projects. This view has been supported in [5], [19] and [4].

\section{IV.4. Benefits of Applying Management Tools in Practice}

According to Table $\mathrm{V}$, the effective communication among construction stakeholders and the enhancement of effective discussion of construction narratives among stakeholders with the highest relative agreement index 0.89 have ranked the highest. This shows that communication is essential on-site. The lack of good communication can spoil a whole project program if it is not communicated effectively to the stakeholders involved.

TABLE V

APPLiCATION OF MANAGEMENT TOOLS In PRACTICE

\begin{tabular}{ccc}
\hline \hline Benefits of Applying Management Tools in Practice & R.A.I & Rank \\
\hline $\begin{array}{c}\text { Effective communication among construction } \\
\text { stakeholders }\end{array}$ & 0.89 & $1^{\text {st }}$ \\
$\begin{array}{c}\text { Enhances effective discuss of construction narratives } \\
\text { among stakeholders }\end{array}$ & 0.89 & $1^{\text {st }}$ \\
$\begin{array}{c}\text { Assist in creating workable goals and objective tools } \\
\text { Better organization of task/work }\end{array}$ & 0.88 & $2^{\text {nd }}$ \\
Enhanced performance at all phases of project & 0.87 & $3^{\text {rd }}$ \\
Proactive identification of risk and move to mitigate \\
$\begin{array}{c}\text { the risk } \\
\text { Better and effective management of project variables }\end{array}$ & 0.86 & $4^{\text {th }}$ \\
$\begin{array}{c}\text { Effective utilization of project benchmarked duration } \\
\text { and cost }\end{array}$ & 0.86 & $5^{\text {th }}$ \\
Effective sourcing, deployment and material & 0.84 & $5^{\text {th }}$ \\
application & 0.83 & $7^{\text {th }}$ \\
\hline \hline
\end{tabular}

Author Survey (2019) RAI--- Relative Agreement Index
Similarly, the timely setting of project goals and object with RAI 0.83 has ranked last. It means that management tools would assist the project managers in setting project goals and objectives earlier at the commencement of the project. In addition, parameters like "assist in creating workable goals" and "objective tools" have RAI 0.88. It shows that management tools can assist in setting construction goals and objectives if deployed appropriately. It also helps in having better program and task organization while the project lasts.

This variable has scored RAI 0.87 in the table. This trend has been supported in [2], in which it is stated that some tools as work breakdown structure and responsibility assignment tools could help facilitate effective project coordination. In order to enable high performance at all phases of construction projects, in line with a submission in [19], [24], and [25], proactive identification of risk and move to mitigate the risk, better and effective management of project variables, effective utilization of project benchmarked duration and cost have RAI 0.86 respectively. This has summarily pointed to the fact that pro-activeness in planning and its implementation is crucial in achieving project benchmarked duration and cost. Cronbachs Alpha test results are presented in Table VI.

The test has been conducted on the collated questionnaire from the four category of respondent sampled. The respondents include Builders, Architects, Quantity surveyors and Civil engineer. The calculated values for the respondents is 0.893 , which is very close to 1.0 . The calculated value from the table is 0.893 while the $\mathrm{P}$ value is 1.00 . The statistics has fallen into the upper quartile range, very close to 1.0. The implication of the data spread is that the range of stability of the data stamina is very high, hence high level of data reliability.

There are tools that are often used on construction sites to improve efficiency. Some of them are listed in Table VII. Some of the top cutting edge tools include agile project software, assignment chart, Critical path method, programme evaluation and review technique, earn value chart and logical frame work.

TABLE VI

RELIABILITY ALPHA TEST

\begin{tabular}{ccc}
\multicolumn{3}{c}{ RELIABILITY ALPHA TEST } \\
\hline \hline Measurement & Cronbach AlphaTest Statistics & $\mathrm{N}$ \\
\hline Builders & 0.893 & 4 \\
Architect & 0.893 & 4 \\
Quantity Surveyor & 0.893 & 4 \\
Civil Engineer & 0.893 & 4 \\
\hline \hline
\end{tabular}

TABLE VII

ADAPTABLE INNOVATIVE MANAGEMENT TOOLS

\begin{tabular}{|c|c|}
\hline Adaptable Innovative Site Practice & Adaptable Tools \\
\hline $\begin{array}{c}\text { Cutting edge monitoring, supervision and } \\
\text { control system for project design, construction } \\
\text { and monitoring }\end{array}$ & $\begin{array}{l}\text { Agile project } \\
\text { management }\end{array}$ \\
\hline $\begin{array}{l}\text { Benchmarking project master objectives and } \\
\text { performance goal monitoring }\end{array}$ & Assignment Chart \\
\hline $\begin{array}{c}\text { Monitoring site operation through ICT based } \\
\text { operation management }\end{array}$ & $\begin{array}{l}\text { Earn chat, CPERT } \\
\text { method and Earn } \\
\text { value management }\end{array}$ \\
\hline $\begin{array}{l}\text { Establishing and benchmarking collaborative } \\
\text { and participatory project decision environment }\end{array}$ & $\begin{array}{l}\text { Logical framework } \\
\text { approach }\end{array}$ \\
\hline
\end{tabular}




\section{IV.5. Comparative Analysis of Construction \\ Professionals Perspective of Inovative Strategies to Best Site Management Practices}

Kendal Thau Coefficient has been derived from analysis of construction professionals on innovative strategies on construction sites and presented in Table VIII. The interdependence of the variables has been tested using Kendal Thau statistical tools. The dynamic nature of construction works is interesting. Enhanced performance at all phases of the project has RAI 0.87 respectively. This has indicated the fact that management practice is essential for work organization Kendal Thau Coefficient of Concordance has been used to carry out a critical analysis of the skewness In addition, all the factors are important, better organization of task/work.

Kendal Thau Coefficient of Concordance has been used to carry out a critical analysis of the skewness of responses.

Kendal Thau Test for Homogeneity of Opinion. Hypothesis: The Hypothesis is in support of research question 5 earlier stated in the introductory section.

$\mathrm{H} 1$ : There is the unity of agreement/opinion about the aptness of the innovative strategy presented.

Ho: there is no unity of agreement/opinion about the aptness of the innovative strategy presented:

$$
U=\sum_{k=1}^{m} \sum_{k=1}^{m}\left(R_{k}^{n}\right)^{2}
$$

where $U=599,943, \quad n=48, \quad m=4, \quad R=([48.41(16)])^{2}=$ $599,943.19=599,943.19$.

$W=$ Kendal coefficient of concordance. Where $U=$ $599,943, m=4, n=48$.

$W=$ Kendal coefficient of concordance. Where $U=$ 599,943, $m=4, n=48$.

$W=12(599,943)-3(42) 48(48+1) 2 /(42) 48(482-1)$.

$W=7,199,316-5,531,904 / 1,768,704$.

$W=0.9427$.
$\mathrm{X}_{2}=m(n-1) W$.

$\mathrm{X}_{2 \mathrm{n}-1}=4(48-1) 599,943.19$.

$\mathrm{X}_{2 \mathrm{n}-1}=177.284$.

X47 tabulated value is 79.08 while $X$ computed is 177.28. Therefore, the calculated value is greater than the tabulated value. The Null hypothesis $\mathrm{Ho}$ is rejected, therefore, there is unity of opinion among the four groups of respondents used for the survey:

$$
\begin{aligned}
& W=12(599,943)-3(42) 48(48+1) 2 / 48(482-1) \\
& W=0.9427 \\
& X_{2}=m(n-1) W \\
& X_{2 n-1}=4(48-1) 599,943.19 \\
& X_{2 n-1}=177.284
\end{aligned}
$$

$\mathrm{X} 47$ tabulated value is 79.08 while $\mathrm{X}$ computed is 177.28 as reflected in Table VIII.

Therefore, the calculated value is greater than the tabulated value.

The Null hypothesis Ho is rejected, and therefore, there is unity of opinion among the four groups of respondents used for the survey. From the opinion of the four groups of respondents presented in the survey, the group consists of Builders, Architects, Quantity surveyors, and Civil engineer that have participated in construction project management.

A careful observation of the skewness has indicated a positive one in the range $79.5 \%$ and $85.8 \%$ by translating mean value to a percentage. In order to validate further this claim's authenticity, the Kendal coefficient can be applicable to determine the homogeneity of opinion among the group of respondents by testing Hypotheses around the parameter.

\begin{tabular}{|c|c|c|c|c|c|c|}
\hline $\begin{array}{c}\text { Comparative Analysis of Construction Professionals Perspective on } \\
\text { Innovative Strategies To Best Site Management Practices }\end{array}$ & Builder & Architect & $\begin{array}{l}\text { Quantity } \\
\text { Surveyor }\end{array}$ & $\begin{array}{c}\text { Civil } \\
\text { Engineer }\end{array}$ & $\begin{array}{l}\text { Mean } \\
\text { Index }\end{array}$ & $\begin{array}{l}\text { Relative Mean } \\
\text { Index }\end{array}$ \\
\hline Detailed information about the project brief should originate from the client & 0.78 .77 & 0.83 & 0.85 & 0.87 & 3.43 & 0.858 \\
\hline Competent people should selected as part of the design team & 0.82 & 0.80 & 0.80 & 0.81 & 3.23 & 0.808 \\
\hline The scope of the project should be adequately managed to ensure quality & 0.86 & 0.80 & 0.82 & 0.78 & 3.26 & 0.815 \\
\hline Design team should be selected based on their professional competence & 0.81 & 0.83 & 0.84 & 0.73 & 3.21 & 0.803 \\
\hline Appropriate procurement system should selected based on project type & 0.78 & 0.81 & 0.78 & 0.72 & 3.09 & 0.773 \\
\hline Appropriate procurement system should selected based on project features & 0.77 & 0.75 & 0.79 & 0.74 & 3.05 & 0.763 \\
\hline $\begin{array}{l}\text { The appropriate procurement system used should align with the terms and } \\
\text { conditions of the contract }\end{array}$ & 0.78 & 0.87 & 0.84 & 0.87 & 3.36 & 0.840 \\
\hline $\begin{array}{c}\text { Site managers should prepare adequate site layout plan before the } \\
\text { commencement of the project }\end{array}$ & 0.77 & 0.78 & 0.83 & 0.82 & 3.20 & 0.800 \\
\hline Mobilization to site should occur after all project preliminaries are placed & 0.76 & 0.88 & 0.84 & 0.83 & 3.31 & 0.828 \\
\hline $\begin{array}{c}\text { Temporary services and accessories should be provided before the } \\
\text { commencement of construction work }\end{array}$ & 0.77 & 0.87 & 0.73 & 0.85 & 3.22 & 0.805 \\
\hline $\begin{array}{l}\text { All building permits should be acquired before mobilization of labor, plant } \\
\text { and equipment to site. }\end{array}$ & 0.75 & 0.86 & 0.76 & 0.88 & 3.25 & 0.813 \\
\hline $\begin{array}{l}\text { All the required PPE equipment and tools should be distributed to all } \\
\text { workers on site, both skilled and unskilled labor. }\end{array}$ & 0.78 & 0.87 & 0.72 & 0.85 & 3.22 & 0.805 \\
\hline Specialization and qualified artisans should be employed & 0.79 & 0.82 & 0.71 & 0.83 & 3.15 & 0.788 \\
\hline Effective training system on the issue of PPE should be worn on site & 0.75 & 0.83 & 0.85 & 0.82 & 3.25 & 0.813 \\
\hline Dedicated and committed workers should be rewarded adequately on site & 0.74 & 0.81 & 0.82 & 0.81 & 3.18 & 0.795 \\
\hline
\end{tabular}

To this end, the following Hypothesis is articulated. This submission is supported by [4], [19], [26], [27], and [28].

TABLE VIII

Professionals Perspective On InNOVATIVE StRategies To Site Management Practice 
Chi Square Test on Comparative Analysis of Respondents Agreement on best Management Strategy:

Ho: No significant difference in respondents' response on innovative Strategy adaptable;

H1: There is a significant difference in respondents' response on innovative Strategy adaptable.

Table IX illustrates the test statistics to validate the acceptance of validity of comparative analysis of respondents' perception of respondents on the best innovative strategy that is adaptable in site management.

The test statistics indicate the acceptance of Null Hypothesis, which indicates no difference in the perception of respondents about the adaptable innovative site strategies

\section{IV.6. Newly Synthesized Innovative Approaches for Managing Construction Projects}

According to the survey contained in Table X, resources synergy oriented procurement route, Adopting User performance expectation oriented procurement system at all phases of the project have ranked at the highest with RAI 0.88 .

This is pointing to the fact that an inclusive system would be an ideal system when output is a design and model based on users' requirements. This would enable the User of a system to model a product based on their performance expectation.

The approach presented here is a type of procurement system that involves individual partner pulling together idea and resources in a way that individual participant at the project has something to present. In this situation, the individual participant is referred to as concessionaire.

This toes the line of submission in [21] and [29]. Userneeds oriented design system, Strategic project management, Engaging Joint venture/collaborative partnership procurement strategy for resource sourcing at all the aspects of the project on-site, Client-professional value management.

The following systems have RAI 0.86 (Consultative decision approach by management, Collaborative decision process, and Adopting Key Performance Indicator based procurement system).

The consultative decision-taking approach entails the management of an organization consulting with relevant stakeholders before taking a position on an issue.

It allows the management to have workers' opinions and interests at heart while making a decision.

TABLE IX

Chi-SQuARE TeSt STATISTICS

\begin{tabular}{cccc}
\hline \hline Parameters & Builders & Arch & Q.S \\
\hline Statistics & Chi & Chi & Chi \\
Asymp.Sig. & 0.328 & 0.328 & 0.329 \\
TestStatistics & 6.078 & 6.927 & 6.06 \\
DF & 6 & 6 & 6 \\
Decision & R.N & R.N & R.N \\
\hline \hline
\end{tabular}

Authors Survey (2019) RAI--- Relative Agreement Index

Legend: R.N:Retain Null Hypothesis

Arch: Architect; Q.S: Quantity Surveyor

Chi square Test. DF: Degree of Freedom
TABLE X

SYNTHESIZED INNOVATIVE APPROACHES FOR MANAGING PROJECTS

\begin{tabular}{ccc}
\hline \hline Innovative Parameters & Mean & Rank \\
\hline Resources synergy oriented procurement route & 0.88 & $1^{\text {st }}$ \\
Adopting User performance expectation oriented & 0.88 & $1^{\text {st }}$ \\
procurement system at all phases of project & 0.87 & $2^{\text {nd }}$ \\
User-needs oriented design system & 0.87 & $2^{\text {nd }}$ \\
Strategic project management & & \\
Engaging Joint venture/ collaborative partnership & & \\
procurement strategy for resource sourcing at all & 0.87 & $2^{\text {nd }}$ \\
aspect of project on site & & \\
Client-professional value management & 0.87 & $2^{\text {nd }}$ \\
Consultative decision approach by management & 0.86 & $3^{\text {rd }}$ \\
Collaborative decision process & 0.86 & $3^{\text {rd }}$ \\
Adopting Key Performance Indicator based & 0.86 & $3^{\text {rd }}$ \\
procurement system & 0.85 & $4^{\text {th }}$ \\
Skill transfer oriented project & 0.85 & $4^{\text {th }}$ \\
Internal control of project environment & 0.85 & $4^{\text {th }}$ \\
Control of project external environment & 0.80 & $5^{\text {th }}$ \\
Social relationship management system on & 0.79 & $6^{\text {th }}$ \\
construction sites & 0.78 & $7^{\text {th }}$ \\
Industrial conflict preempting decision system & & \\
Engaging conflict early warning and danger signal \\
alert system on projects
\end{tabular}

In addition, management could adopt key performance indicator as means of managing site, actions and opinion of the management in this sense should center on the benchmarked key performance indicators for the project.

This view has been supported in [3] and [19]. The studies have submitted that project managers should always benchmark factors in the form of key performance parameters. This would assist the project to fare in the right direction. It has been described by [3] as a diamond approach to make a project grow effectively. In the study, three types of new management practices have RAI 0.85: Skill transfer-oriented project, Internal control of project environment, and Control of the external project environment.

These three types of management system entail designing and configuring the project to conform to the kind that would enable workers and professionals to enjoy the benefits of skill transfer while the project lasts, also advocated for the control of parameters that are rare within the project portfolio. This includes parameters such as finance, tools, and equipment, human resources, project innovation, risk, and risk mitigation on the project among others.

The social relationship management system on construction sites has RAI 0.80 and Industrial conflict preempting decision system has RAI 0.79 . The social relationship management style involves achieving the project success through improving social relationships on a project.

This involves harnessing the psychological and the emotional disposition of project participants, thereby peaceful cultivation atmosphere of the relationship among stakeholders, and maintaining a sense of unity.

There is consonance between maintaining a social relationship and engaging conflict preempting decision systems on a project.

The social relationship approach would bring the elimination of conflict and crisis on the project. 


\section{IV.7. Critical Success Factors in Applying Innovative Approach on Construction Sites}

Critical success factors in applying innovative approaches on construction sites are presented in Table $\mathrm{XI}$, setting up monitoring and control systems to match project goals with progressive performance RAI 0.87 and Establishing project objectives. Performance goal RAI 0.87 has the highest scores.

This implies that project performance, when monitored objectively on a project, has the potential of leading the project to a successful end, alongside this is setting and benchmarking project objectives right at the outset of a project. It would enable project managers to center on the needful while coordinating other aspects of the project.

Similarly, the following success factors have the lowest RAI value of 0.84 : setting up an effective strategy for monitoring site operations, setting up an early warning system at various stages of project work, and enthronement of reward, welfare, and compensation mechanism on site.

All the critical success factors presented in the table are all vital in achieving success when applying innovations on a project.

One of the innovative approaches to the project is setting up a strategy for monitoring site operations and putting in place an early warning system for early detection of problems and challenges on sites. In addition, one of the innovative ways that many managers rarely follow is un-relented reward and compensation of project workers on sites.

This approach tends to elicit voluntary cooperation and commitment from workers to the management, thereby leading to higher productivity.

Moreover, maintaining a collaborative and participatory project decision scenario has RAI 0.86, maintaining internal and external corporate social responsibility among stakeholder has RAI 0.86. Strategic stakeholder management on project work has RAI 0.85 . Synergizing project internal and external environment variables have RAI 0.85 .

TABLE XI

CRITICAL SUCCESS FACTORS THAT INFLUENCES INNOVATIVE APPROACH ON CONSTRUCTION SITES

\begin{tabular}{ccc}
\hline \hline Success Factors & RAI & Rank \\
\hline $\begin{array}{c}\text { Setting up monitoring and control system to match } \\
\text { project goal with performance }\end{array}$ & 0.87 & 1 st \\
$\begin{array}{c}\text { Establishing project objective and performance goal } \\
\text { Setting up an effective strategy for monitoring site } \\
\text { operations }\end{array}$ & 0.87 & 1 st \\
$\begin{array}{c}\text { Maintaining collaborative and participatory project } \\
\text { decision scenario }\end{array}$ & 0.86 & 2nd \\
$\begin{array}{c}\text { Maintaining internal and external corporate social } \\
\text { responsibility among stakeholder }\end{array}$ & 0.86 & 2nd \\
$\begin{array}{c}\text { Strategic stakeholder management on project work } \\
\quad \begin{array}{c}\text { variables } \\
\text { Synergizing project internal and external environment }\end{array}\end{array}$ & 0.85 & $3 \mathrm{rd}$ \\
$\begin{array}{c}\text { Organizing system for procuring, storing and managing } \\
\text { materials on sites }\end{array}$ & 0.85 & $3 \mathrm{rd}$ \\
$\begin{array}{c}\text { Managing stakeholders and project expectations } \\
\text { Setting up proactive system to trouble shoot problems on } \\
\text { site }\end{array}$ & 0.85 & 3rd \\
\hline \hline
\end{tabular}

IV.8. Adaptive Regression-Based Correlation Matrix of Factors for Modelling Innovative Site Management Practice Using Factor Reduction Method

The reduced form of the factors is presented in Table XII. Only factors with values that range from 0 to 1 Eigenvalue have been picked. The factors with higher Eigenvalue that have been very close to 1 have been further selected to be the representative factor of the remaining factors, and this has been presented in Table 1.9. Three emerging factors have been presented in Table XIII, group factors 1,2 , and 3. The factors have been rotated, and three major representatives of the 21 variables have been used for the site management innovative models. Group 1 and Group factor 2 have six component variables that form the nucleus of the models.

The variables consist of parameters that could be used on the on-site project as innovative approaches to site management on site. The models can be used interchangeably in line with contingency theory that states that no theory is sufficient in itself in solving problems but the interplay of more than one theory.

Therefore, the models can be deployed in pairs.

\section{IV.9. Complimentary Management tools for Developed Management Practice}

In Table XIV, Complimentary Management tools for the developed management practice have been presented.

The presentation consists of management practice and corresponding tools of practice. For instance, Setting up a monitoring and control system to match project goal with progressive performance as a form of practice can be achieved with the aid of a tool called "Agile project management,".

It uses Microsoft Excel spreadsheet for creating a solution to the problem of logistic management on the project. Likewise, establishing project objective and performance goal can be carried out with the aid of a responsibility assignment chart.

TABLE XII

CORRELATION MATRIX FOR MODELLING INNOVATIVE SITE MANAGEMENT PRACTICE USING FACTOR REDUCTION METHOD

\begin{tabular}{cccccc}
\hline \hline F1 & F2 & F3 & F4 & F5 & F6 \\
\hline 1.00 & & & & & \\
.903 & 1.00 & & & & \\
& 0.903 & 1.00 & & & \\
& & & & & \\
& & & & & \\
& & & & 0.90 & \\
& & & & & \\
F9 & F10 & F11 & F12 & F13 & F14 \\
1.00 & 1.00 & & & & \\
& 0.922 & 1.00 & & & \\
& 0.993 & & 1.00 & & \\
& 0.904 & & 0.843 & 1.00 & \\
& 0.99 & & 0.935 & & \\
& 0.993 & & & 0.978 & \\
& 0.994 & & 0.943 & & 0.978 \\
\hline \hline
\end{tabular}

Author Survey (2019)RAI--- Relative Agreement Index 
TABLE XIII

ROTATED COMPONENT MATRIX ${ }^{\mathrm{a}}$

\begin{tabular}{|c|c|c|c|}
\hline \multirow[b]{2}{*}{ Factors' Characteristics } & \multicolumn{3}{|c|}{ Component } \\
\hline & 1 & 2 & 3 \\
\hline Innovative Parameter & & -.732 & \\
\hline Strategic project management & & -.933 & \\
\hline Client-professional value management & & -.777 & \\
\hline Collaborative decision process & & & .845 \\
\hline Internal control of project environment & & & .988 \\
\hline External Skill transfer oriented project & -.969 & & \\
\hline User-needs oriented design system & & .875 & \\
\hline Consultative decision approach by management & & .901 & \\
\hline Industrial conflict preempting decision system & .976 & & \\
\hline $\begin{array}{c}\text { Engaging conflict early warning and danger } \\
\text { signal alert system }\end{array}$ & .852 & & \\
\hline $\begin{array}{l}\text { Social relationship management system on } \\
\text { construction sites }\end{array}$ & .993 & & \\
\hline $\begin{array}{c}\text { Adopting User performance expectation } \\
\text { oriented procurement system at all phases of } \\
\text { project }\end{array}$ & .975 & & \\
\hline Resources synergy oriented procurement route & & .993 & \\
\hline $\begin{array}{c}\text { Adopting Key Performance Indicator based } \\
\text { procurement system }\end{array}$ & & .995 & \\
\hline $\begin{array}{l}\text { Engaging Joint venture/ collaborative } \\
\text { partnership procurement strategy for resource } \\
\text { sourcing on site }\end{array}$ & .993 & & \\
\hline Managing stakeholders and project expectations & .975 & & \\
\hline $\begin{array}{c}\text { Synergizing project internal and external } \\
\text { environment variables }\end{array}$ & & .993 & \\
\hline $\begin{array}{l}\text { Resources synergy oriented procurement route } \\
\text { Adopting User performance expectation }\end{array}$ & & .995 & \\
\hline $\begin{array}{c}\text { oriented procurement system at all phases of } \\
\text { project }\end{array}$ & .852 & & \\
\hline User need oriented design & .993 & & \\
\hline Strategic project management & .975 & & \\
\hline Collaborative procurement system & & .993 & \\
\hline Client professional value management & .975 & & \\
\hline $\begin{array}{l}\text { Extraction Method: Principal Component Analy } \\
\text { Varimax with Kaiser Normaliz }\end{array}$ & $\begin{array}{l}\text { ysis. R } \\
\text { zation. }\end{array}$ & otation & Method: \\
\hline
\end{tabular}

TABLE XIV

MAPPING INNOVATIVE MANAGEMENT PRACTICE WITH RELEVANT INNOVATIVE TOOL

\begin{tabular}{|c|c|}
\hline Innovative Management Practice & Innovative Tools \\
\hline $\begin{array}{l}\text { Setting up monitoring and control system } \\
\text { match project goal with progressive } \\
\text { performance }\end{array}$ & Agile project management \\
\hline $\begin{array}{l}\text { Establishing project objective and } \\
\text { performance goal }\end{array}$ & $\begin{array}{c}\text { Assignment Responsibility } \\
\text { chart }\end{array}$ \\
\hline $\begin{array}{l}\text { Setting up an effective strategy for } \\
\text { monitoring site operations }\end{array}$ & $\begin{array}{l}\text { Critical Path methods, Earn } \\
\text { value management }\end{array}$ \\
\hline $\begin{array}{l}\text { Maintaining collaborative and participatory } \\
\text { project decision scenario }\end{array}$ & $\begin{array}{l}\text { Logical framework } \\
\text { approach }\end{array}$ \\
\hline $\begin{array}{l}\text { Maintaining internal and external corporate } \\
\text { social responsibility among stakeholder }\end{array}$ & $\begin{array}{l}\text { Formalized structure, } \\
\text { responsibility assignment }\end{array}$ \\
\hline $\begin{array}{c}\text { Strategic stakeholder management on } \\
\text { project work. }\end{array}$ & Formal and risk Analysis, \\
\hline $\begin{array}{c}\text { Synergizing project internal and external } \\
\text { environment variables }\end{array}$ & Critical chain method \\
\hline $\begin{array}{l}\text { Organizing system for procuring, storing } \\
\text { and managing materials on sites }\end{array}$ & Project financial evaluation \\
\hline $\begin{array}{c}\text { Managing stakeholders and project } \\
\text { expectations }\end{array}$ & $\begin{array}{l}\text { work breakdown structure, } \\
\text { Earn value management }\end{array}$ \\
\hline $\begin{array}{l}\text { Setting up proactive system to trouble shoot } \\
\text { problems on site }\end{array}$ & Formalized risk analysis \\
\hline $\begin{array}{l}\text { Setting up an early warning systems at } \\
\text { various stages of project work. }\end{array}$ & Critical chain method \\
\hline $\begin{array}{l}\text { Enthronement of reward, welfare and } \\
\text { compensation mechanism on site }\end{array}$ & Earn value management, \\
\hline
\end{tabular}

Setting up an effective strategy for monitoring site operations can also be achieved using Critical Path methods. The chart would help the manager to identify items that are critical to the success of a particular operation. In addition, earn value management, maintaining a collaborative and participatory project decision scenario could be carried out using the logical framework approach. It would enable a manager to make a wise combination of an optimized alternative through multi-criteria-comparison-of parameters. [22], [23], [30][32]. Moreover, maintaining internal and external corporate social responsibility among stakeholders as a practice could be achieved using Formalized structure tools and responsibility assignment tools. Strategic stakeholder management on project work can be matched with formal and risk summary tool. Synergizing project internal and external environment variables would be compatible with the critical chain method tool.

Organizing system for procuring, storing, and managing materials on sites with project financial evaluation tool while managing stakeholders and project expectations would be better achieved using work breakdown structure tool.

Similarly, earn value management and setting up a proactive system to trouble-shoot problems on site can be carried out with the aid of the critical chain method. In contrast, enthronement of reward, welfare, and compensation mechanism on-site would be better achieved through the adoption of earn value management as a tool.

However, the idea of matching the management practice to a corresponding tool is supported in [2], recommending some of the following management tools for use on construction projects: formalized structure, agile project management, earned value management, formalized risk analysis, critical chain method, logic framework approach and critical chain method. The suggested management practices in this study cover management issues surrounding design, planning, costing, managing, and control of the project, cost analysis, construction, and post-occupancy evaluation. In Table XV, the statistics of respondents' educational qualification is outlined.

All the respondents used for the study are qualified and are professionally qualified. 16 respondents has Higher National Diploma, 33 respondents are with BSc. Qualification, 15 with Master degree, 7 with Master of Business Administration corticated, while 9 respondents are with $\mathrm{PhD}$ certificates.

The breakdown illustrates the wealth of experience possessed by the respondents. All the categories of the respondents are well experienced considering their education background.

TABLE XV

RESULT OF RESPONDENTS EDUCATIONAL QUALIFICATION

\begin{tabular}{ccc}
\hline \hline Degree & Frequency & Percentage $(\%)$ \\
\hline H.N.D & 16 & 20.00 \\
B.S.C & 33 & 41.25 \\
M.Sc & 15 & 18.75 \\
M.B.A & 7 & 8.75 \\
Ph.D & 9 & 11.25 \\
Total & 80 & 100 \\
\hline \hline
\end{tabular}


Respondent's breakdown is illustrated in Table XVI.

33 Builders, which constitute $41.25 \%$ of sampled respondents, have been used, 16 Architects with $19.98 \%$ composition have been used, 14 Civil engineer occupies $17 \%, 11$ Electrical engineer occupies $14.5 \%$ while 10 Mechanical engineer which constitutes $12.5 \%$ of the respondents have been used in this study. Builders, Architect, Civil engineer have formed the crux of highest respondents and the bulk of professionals that manages construction sites, therefore at the frontline of people that use innovative system on sites. Gains of deployment of deployment of management tools in construction practice are described in Table XVII. Collaborative stakeholders communication on project, and proactive project resources scheduling have been unanimously ranked $1^{\text {st }}$ by Architect and Builders. Benchmarking improvement initiative at different stages of projects and effective planning of time and cost resources have ranked $3^{\text {rd }}$.

Proactive scheduling and determination of project and sites goals and objectives alongside adequate allocation, supply and utilization of materials have ranked least. The management tools have offered an opportunity for collaborative engagement on site because of its multidisciplinary content. It assists in creating improvement in the way operations are carried out on projects. Adopting innovative management tools also helps to achieve an effective scheduling and management of resources.

The gains presented can change the game of project management on site when effectively deployed. In conventional construction management system, client and customers are supposed to be in cordial relationship and individual stakeholder need social responsibility as presented in this study.

TABLE XVI

RESULTS OF RESPONDENTS PROFESSION

\begin{tabular}{ccc}
\hline \hline Profession & Frequency & Percentage (\%) \\
\hline Builder & 33 & 41.25 \\
Architect & 16 & 19.98 \\
Quantity Surveyor & 16 & 7.25 \\
Civil Engineer & 14 & 17 \\
Electrical Engr & 11 & 13.75 \\
Mechanical Engr & 10 & 12.50 \\
\hline \hline
\end{tabular}

TABLE XVII

GaINS OF DEPLOYMENT Of MANAGEMENT TOOLS IN PRACTICE

\begin{tabular}{|c|c|c|c|c|}
\hline Gains of deployment & Arch & Rank & Bldr & Rank \\
\hline $\begin{array}{l}\text { Collaborative stakeholders communication } \\
\text { on projects }\end{array}$ & 0.78 & $1^{\mathrm{st}}$ & 0.78 & $1^{\mathrm{st}}$ \\
\hline Proactive project resources scheduling & 0.78 & $1^{\text {st }}$ & 0.73 & $2^{\text {nd }}$ \\
\hline $\begin{array}{l}\text { Benchmarking improvement initiatiative at } \\
\text { different stages of projects }\end{array}$ & 0.75 & $3^{\text {rd }}$ & 0.71 & $7^{\text {th }}$ \\
\hline $\begin{array}{l}\text { Effective planning of resources of time and } \\
\text { cost on projects }\end{array}$ & 0.75 & $3^{\text {rd }}$ & 0.70 & $8^{\text {th }}$ \\
\hline $\begin{array}{l}\text { Excellent management of human resource and } \\
\text { itinerary }\end{array}$ & 0.63 & $4^{\text {th }}$ & 0.68 & $9^{\text {th }}$ \\
\hline Effective risk identification and mitigation & 0.62 & $5^{\text {th }}$ & 0.64 & \\
\hline Enhanced allocation of work structure & 0.56 & $6^{\text {th }}$ & 0.59 & $11^{\text {th }}$ \\
\hline $\begin{array}{l}\text { Improved communication among projects } \\
\text { stakeholders }\end{array}$ & 0.53 & $7^{\text {th }}$ & 0.52 & $12^{\text {th }}$ \\
\hline $\begin{array}{l}\text { Adequate allocation, supply and utilization of } \\
\text { materials }\end{array}$ & 0.51 & $8^{\text {th }}$ & 0.51 & $13^{\text {th }}$ \\
\hline $\begin{array}{l}\text { Proactive scheduling and determination of } \\
\text { project and sites goals and objectives }\end{array}$ & 0.49 & $9^{\text {th }}$ & 0.50 & $14^{\text {th }}$ \\
\hline
\end{tabular}

For instance as demonstrated social responsibility among stakeholders is an important issue that influences project success. Therefore, social responsibility among stakeholders as a practice could be achieved using specialized structures or a formalized structure tools and responsibility assignment tools as reflected in Table XVII.

Engaging strategic stakeholder management on project work can be matched with formal and risk summary tool. Synergizing project internal and external environment variables would be compatible with the critical chain method tool. Organizing system for procuring, storing, and managing materials on sites with project financial evaluation tool while managing stakeholders and project expectations would be better achieved using work breakdown structure tool.

Similarly, Earn value management and Setting up a proactive system to trouble-shoot problems on site can be carried out with the aid of the critical chain method. In contrast, Enthronement of reward, welfare, and compensation mechanism on-site would be best achieved through the adoption of Earn value management as a tool. However, the idea of matching the management practice to a corresponding tool is supported in [2], recommending some of the following management tools for use on construction projects: formalized structure, agile project management, earned value management, formalized risk analysis, critical chain method, logic framework approach and critical chain method. The suggested management practices in this study cover management issues surrounding design, planning, costing, managing, and control of the project, cost analysis, construction, and post-occupancy evaluation. In Table XVIII, the results of Man Whitney U Test are illustrated. The P-value calculated is 1.5 for all the variables.

This indicates higher values than the P.value 0.05 . The null hypotheis is retained at 2 degrees of freedom. The implication of the results is that there is no significant agreement in the ranking of opinion on gains of innovative strategy deployment on sites Albeit, there are benefits in engaging good management practice, it comes with advantages, such as the better organization of task/work and enhanced performance at all phases of projects. This has indicated the fact that management practice is essential for work organization in order to enable high performance at all the phases of construction projects. There tends to be a consensus regarding the perception of professional about some key innovative management practices that could be introduced on-site.

There has been an agreement on the following innovative methods: detailed information about the project brief to originate from the client, competent people should be selected as part of the design team, the scope of the project should be adequately managed to ensure quality, the appropriate procurement system used should align with the terms and conditions of the contract and dedicated, and committed workers should be rewarded adequately on site. 
TABLE XVIII

MAN WhitNey U TEST ON RESPONDENTS VIEW ON GAINS OF DEPLOYMENT OF MANAGEMENT TOOLS IN PRACTICE*

\begin{tabular}{cccccc}
\hline \hline $\begin{array}{c}\text { Gains of deployment Of } \\
\text { Management Tools In Practice }\end{array}$ & Arch & Bldr & $\mathrm{N}$ & $\mathrm{R}$ & Mean \\
\hline Collaborative stakeholders & 1.0 & 1.0 & 2 & 1.5 & 3.0 \\
communication on projects & 2.0 & 2.0 & 2 & 1.5 & 3.0 \\
Proactive project resources & 1.0 & 1.0 & 2 & 1.5 & 3.0 \\
scheduling & 2.0 & 2.0 & 2 & 1.5 & 3.0 \\
Benchmarking improvement & 1.0 & 1.0 & 2 & 1.5 & 3.0 \\
initiative at different stages of & 2.0 & 2.0 & 2 & 1.5 & 3.0 \\
projects & 1.0 & 2.0 & 2 & 1.5 & 3.0 \\
Effective resources of time and & 2.0 & 2.0 & 2 & 1.5 & 3.0 \\
$\quad$ cost on projects & 1.0 & 1.0 & 2 & 1.5 & 3.0 \\
Excellent management of human & 2.0 & 1.0 & 2 & 1.5 & 3.0 \\
resource and itinerary & 1.0 & 2.0 & 2 & 1.5 & 3.0 \\
Effective risk identification and & 2.0 & 2.0 & 2 & 1.5 & 3.0 \\
$\quad$ mitigation & 1.0 & 2.0 & 2 & 1.5 & 3.0 \\
Enhanced allocation of work & 2.0 & 2.0 & 2 & 1.5 & 3.0 \\
$\quad$ structure & 1.0 & 2.0 & 2 & 1.5 & 3.0 \\
Improved communication among & 2.0 & 2.0 & 2 & 1.5 & 3.0 \\
projects stakeholders & 1.0 & 2.0 & 2 & 1.5 & 3.0 \\
Adequate allocation, supply and & 2.0 & 2.0 & 2 & 1.5 & 3.0 \\
$\quad$ utilization of materials & & & & & \\
Proactive scheduling and & 1.0 & 2.0 & 2 & 1.5 & 3.0 \\
determination of project and sites & 1.0 & & & & \\
goals and objectives & & & &
\end{tabular}

*Hypothesis:

Ho: There is no significant agreement in the ranking of opinion on gains of innovative strategy deployment on sites.

$\mathrm{H} 1$ : There is significant agreement in the ranking of opinion on gains of innovative strategy deployment on sites.

This study has developed innovative strategies that could be used on-site and framework of application in the form of a logic regression model.

Most of the parameters of the model are client-projectstakeholders oriented. For instance, some of them include resources synergy oriented procurement route, adopting User performance expectation oriented procurement system at all phases of the project, consultative decision approach by management, collaborative decision process, and adopting key performance indicator based procurement system.

The consultative decision-taking approach entails the management of an organization consulting with relevant stakeholders before taking a position on an issue. It allows the government to have workers' opinions and interests at heart while making decisions.

This points to the fact that an inclusive system would be an ideal system when output is the design and model based on users' requirements.

This would enable the User of a system to model a product based on their performance expectation. The system presented here is a type of procurement system that involves individual partner pulling together idea and resources in a way that individual participant at the project has something to present.
In this situation individual participant is referred to as concessionaire. Finally, there should be different strokes for different folks.

There are different tools that are applicable to different management system.

The study has attempted at addressing this by recommending different tools for each of the innovative management techniques developed, e.g., Setting up monitoring and control system to match project goal with progressive performance as a form of practice can be achieved with the aid of tool called "Agile project management". It uses Microsoft Excel spreadsheet for creating a solution to the problem of logistic management on a project.

Likewise, organizing systems for procuring, storing, and managing materials on sites with Project financial evaluation tool while managing stakeholders and project expectations would be best achieved using the work breakdown structure tool, among others.

\section{Conclusion and Recommendation}

According to the findings in the study, certain site management practices have been discovered to be prevalent, for instance, client request forming the basis of design brief and configuration, selection of design team based on profiled past project performances, and profiling designs based on the project scope.

The limitation of the existing methods has given rise development of new strategies.

Many factors profiled have been been the bane of site management practice at the research location, such as project-related factors, project team members related factors, procurement route related factors, and external related factors.

Great attention is needed in order to address the factors that are external to the project since they are sometimes out of project manager control and have the potential to influence project success negatively, e.g. provision of resources and alternative resources.

Moreover, there are challenges involved in the administration of site management practices. For instance, there is a tendency for project managers or stakeholders to commit an error of judgment in getting the right resources, and difficulty in calibrating the types of resources needed has the potential to hinder the extent of success desirable on-site if not correctly addressed, likewise, non-compliance with site instructions as laid down in the work program alongside flaunting building regulations have been known to have a negative impact on construction projects. 


\section{Appendix}

TABLE A1

ROTATED FACTORS

\begin{tabular}{|c|c|c|c|}
\hline \multicolumn{4}{|c|}{ Rotated Component Matrix ${ }^{\mathrm{a}}$} \\
\hline & \multicolumn{3}{|c|}{ Component } \\
\hline & 1 & 2 & 3 \\
\hline Detlinfo & & -.732 & \\
\hline Comptpeople & & -.933 & \\
\hline Thescope & & -.777 & \\
\hline Desingteam & & & .845 \\
\hline Apprpratprocu & & & .988 \\
\hline Settgupmeasure & -.969 & & \\
\hline TheapprpProcmt & & .875 & \\
\hline Sitemgrlayout & & & \\
\hline Mobilizatntosite & & .901 & \\
\hline Tempservices & .976 & & \\
\hline Allbldgpermit & .852 & & \\
\hline AllrqrdPPE & .993 & & \\
\hline Specializatqualified & .975 & & \\
\hline Effectivetraining & & .993 & \\
\hline Dedicateandcommwkrs & & .995 & \\
\hline AdoptingKPIindcator & .993 & & \\
\hline Managingstakehldr & .975 & & \\
\hline Intnalandextstkholdermgt & & .993 & \\
\hline Resurcesynergyprocurement & & .995 & \\
\hline Userperfmanceexpectation & .852 & & \\
\hline Userneedorienteddesign & .993 & & \\
\hline Strategicprojmgt & .975 & & \\
\hline Collaboratiprocusystem & & .993 & \\
\hline Clientprofevaluemanagement & .975 & & \\
\hline Extr & ent $\mathrm{An}$ & & \\
\hline n 4 iterations & 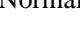 & & \\
\hline
\end{tabular}

\section{Acknowledgements}

The support of Center for Innovation and Research Development (CUCRID) and Building Informatics Research Group members of Building Technology Department of College of Science and Technology Covenant University Ota, Ogun state, Nigeria is appreciated for various contributions and funding of the APC.

\section{References}

[1] Olanrewaju, A. L., \& Abdul-Aziz, A. R. (2015). Building Maintenance Processes, Principles, Procedures, Practices, and Strategies. In Building Maintenance Processes and Practices. Springer. Singapore. June 2015. Pp.79-129.

[2] Janakootalova, Liberma, and Tetrevova (2014) Towards Improving Site Management. Procedia Social and Behavioral Sciences.150C Page 678-689.

[3] Shenhar and Dvir (2007) In search of project classification: a nonuniversal approach to project success factors, Research Policy, 27(9): 915-925.

[4] Ugwu and Attah(2016) Ugwu, O. O. and Haupt T. C., Key Performance Indicators and Assessment Methods for Infrastructure Sustainability - A South African Construction Industry Perspective, Building \& Environment, Vol. 42, Number 2, 2007, pp. 665

[5] Frimpong, Oluwoye, and Crawford (2004) Causes of delay and cost overruns in construction of groundwater projects in developing countries; Ghana as a case study, International Journal of Project Management, Vol. 21, Number 5, pp.45

[6] Carrillo, P. and Chinowsky, P (2006) Exploiting Knowledge Management: The Engineering and Construction Perspective. Journal of Management in Engineering, Vol. 22, No. 1, pp. 2-10.

[7] Pinto, J.K. and Slevin, D.P. Critical success factors in R\&D projects, Research-Technology Management, 1989, 32(1): pp.3135

[8] Kavanagh, D. and Naughton, E. (2009) Innovation \& project management - exploring the links, PM World Today, 2009, vol. $\mathrm{XI}$, issue IV, pp. 1-7

[9] Proverbs, DG, Holt, G D and Cheok, H Y (2000) construction industry problems; the views of UK construction directors. In; Akintoye, A (Ed.), 16th annual ARCOM conference, 6-8 September 2000, Glasgow Caledonian University. Association of researchers in construction management, vol.1, 73-81

[10] Creswel John.W (2016) Reflection on the MMIRA The Future of Mixed Methods Task Force Report. Journal of Mixed Method Research. Pg45-65.

[11] Osiyevskyy, O., Dewald, J. (2015), Explorative versus exploitative business model change: The cognitive antecedents of firm-level responses to disruptive innovation. Strategic Entrepreneurship Journal, 9(1), pp.58-78.

[12] Sudhir, Chitnis, Nehal, Despande, and Arvind (2016) An Investigative Study For Smart Home Security: Issues, Challenges, and Countermeasure. Wireless Sensor Network. 8(4). Pp. 65-69. Pp 491-506.

[13] Tangkar Martino and Arditi David (2000) Innovation in the Construction Industry. Dimensi Teknik Sipil, Vol. 2, No. 2, September 2000, Hal. 96 - 103.

[14] Serpell, A., and Ferrada, X. (2006). A Competency Framework for Construction Supervisors in Developing Countries. CIB W107 Construction in Developing Countries International Symposium. 18 - 20 January 2006, Santiago, Chile. (10). pp.234-245.

[15] Hughes (2010), Hughes, W. P. (2010) Built environment education, research, and practice: Integrating diverse interests to make an impact In Laryea, S., Leininger, R. and Hughes, W. (Eds) Procs West Africa Built Environment Research (WABER) Conference, 27-28 July 2010, Accra, Ghana, pp.1-8.

[16] Marjasalo, A., Koskenvesa, A., Tolonen, T., and Koskela, L. (2011). Time Allocation of Site Management. Proceedings of the 19th Annual Meeting of the International Group for Lean Construction. Lima, Peru. pp.124-138.

[17] Nitithamyong and Skibniewski (2004), Web-based construction 
management project systems: how to make them successful? Automation in Construction. Vol. 13, pp.10-25.

[18] Hirano, H. (1995). 5 Pillars of the Visual Workplace. Productivity. Cambridge Press. $3^{\text {rd }}$ Edition. pp13-19.

[19] Arnaboldi, Azzone and Savoldelli (2004) Managing public sector project: the case of the Italian Treasury Ministry. International Journal of Project management, Vol. 22, Number 3, 2004, pp 213-223.

[20] Robinson (2004), Robbins, ST, and Coulter, M. (2007). Management (8th Edition). UK; Prentice Hall. Pp..21-35.

[21] Arnaboldi, Azzone and Savoldelli (2004) Managing public sector project: the case of the Italian Treasury Ministry. International Journal of Project management, vol. 22, Number 3, 2004, pp 213223.

[22] Amusan, M. Lekan, Clinton Aigbavboa, Aremu J. Adekunle \& Adediran C. Ayodele (2020) Developing Sustainable Urban-Rural Housing System: Formulating Implementation Framework Using Block Diagram And Heuristic Algorithm System. International Journal of Mechanical and Production Engineering Research and Development (IJMPERD) ISSN (P): 2249-6890; ISSN (E): 2249_ 8001 Vol. 10, Issue 3, Jun 2020, pp.3429-3438

[23] Amusan Lekan, Andrew Shalem Ashiga, Emetere Moses Eterigho, Ojelabi Raphael Abiodun (2020) Mechanically InducedSound Approach to Producing Alternative Electricity. Boreal Environment Research Journal. 25[7\}. Pp. 2-25.

[24] Hasan M.F, and Mohammed M.S (2018). Time Overrun Model for Construction Projects in Iraq by Using Fuzzy Logic. International Journal of Civil Engineering and Technology, Vol. 9 (Issue 11): 2593-2607.

[25] Hamid, W., Waterman, A., Analysis of the Main Causes of Cost Overruns in Construction Industry in Developing Countries and the UK, (2018) International Review of Civil Engineering (IRECE), 9 (3), pp. 105-113. doi: https://doi.org/10.15866/irece.v9i3.14525

[26] Taraziya, R., Abd Ali, R., Survey on the Most Significant Factors Affecting the Delivery Process of Construction Activities During Execution Phase in Iraq, (2020) International Review of Civil Engineering (IRECE), 11 (3), pp. 114-120. doi: https://doi.org/10.15866/irece.v11i3.17700

[27] Aswed, G., Mohammed, H., Ahmed, M., Factors Affecting Safety in Construction Projects, (2020) International Review of Civil Engineering (IRECE), 11 (3), pp. 135-140. doi: https://doi.org/10.15866/irece.v11i3.17142

[28] Taufik Dwi Laksono (2019) Causes of Cost Overruns in Construction Industry International Journal of Civil Engineering and Technology. vol 10(5), pp.117-120.

[29] Dewa Ketut Sudarsana, Putu Ari Sanjaya (2019), Development of Delay Claim with a Traffic Volume Approach of the Road National Improvement Project. International Journal of Civil Engineering and Technology Vol 10, No 3, pp.142-147.

[30] Krasniqi, R., Doci, I., Shala, A., Berisha, R., Regulation of Traffic Flow in Small Cities with High Number of Vehicles: Case of Malisheva City - Kosovo, (2018) International Review of Civil Engineering (IRECE), 9 (4), pp. 161-167. doi: https://doi.org/10.15866/irece.v9i4.14300

[31] Sanchez-Matellanes, S., Rodriguez-Hernandez, J., Castro-Fresno, D., Collazos-Arias, F., Review of Climate Risk Analysis in Infrastructures, (2018) International Review of Civil Engineering (IRECE), 9 (1), pp. 1-10. doi: https://doi.org/10.15866/irece.v9i1.13465

[32] Aswed, G., Mohammed, H., Ahmed, M., Factors Affecting Safety in Construction Projects, (2020) International Review of Civil Engineering (IRECE), 11 (3), pp. 135-140. doi: https://doi.org/10.15866/irece.v11i3.17142

\section{Authors' information}

${ }^{1}$ Building Technology Department. College of Science and Technology. Covenant University. Ota. Ogun State. Nigeria.

${ }^{2}$ Faculty of Engineering and Built Environment, Department of Construction Management and Quantity Surveying. University of Johannesburg, South Africa.

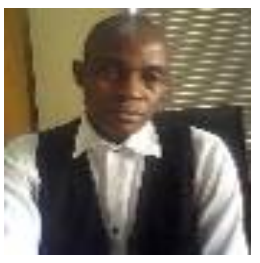

Dr. Lekan Amusan of Covenant University, Ota. Ogun State Nigeria, was born in Osun State, Nigeria on August 16,1972. He holds BSc. in Building and MSc. in Construction Management from University of Lagos, Akoka, Lagos State Nigeria respectively. He as well holds $\mathrm{PhD}$ in Construction Management from Covenant University. Ota. Ogun State, Nigeria. Dr. Amusan is an astute Builder with 23 years professional experience. $\mathrm{He}$ is an academia at the Covenant University. Nigeria. $\mathrm{He}$ is a registered member of Council of Registered Builders of Nigeria and Nigeria Institute of Building.

E-mail: lekan.amusan@covenantuniversity.edu.ng

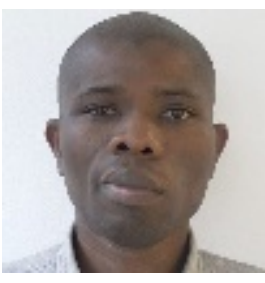

Professor Clinton Aigbavboa is a Full Professor of Sustainable Human Development in the Department of Construction Management and Quantity Surveying, University of Johannesburg, South Africa; with a multidisciplinary research focus on the built environment. Before entering academia, he was involved as quantity surveyor on several infrastructural projects, both in Nigeria and South Africa. He holds a PhD in Engineering Management and has published over 500 research papers in his areas of interest. He has extensive knowledge in practice, research, training and teaching. He holds HND (Auchi Poly.); MTECH (UJ); PhD (UJ); Certificate in Good Governance (UNISA) and NRF Ratings is Y2.

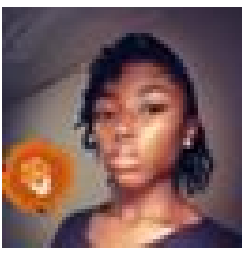

Ms. Tolulope Olubiyi, Building Engineer at Construction Kaiser Limited (CKL) was born in Abeokuta in 1995. She is Building Engineer at Company LEGO Consult Internship. She graduated from Covenant University in Second Class Upper Division with BSc. Hons. Building Technology. She was employed in Jan $2017-$ Aug 2017. In addition, she holds Bachelor of Science - BSc. Degree and graduated in 2014 - 2019. She is a registered member of Nigerian Institute of Building.

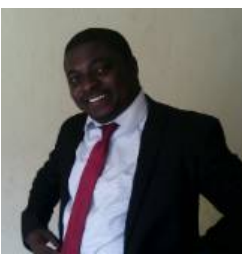

Mr. Ogunbayo Babatunde is an academia of Covenant University, Ota. Ogun State Nigeria, was born in Ogun State, Nigeria on 1982. He holds HND Building Technology from Osun State Polytechnic, MSc. Housing University of Ibadan. He is an academia at the Covenant University. Nigeria. He is a registered member Registered Builders of Nigeria. 